Article

\title{
Availability of Nickel in Soil Evaluated by Various Chemical Extractants and Plant Accumulation
}

\author{
Monika Jakubus ${ }^{1, *(D)}$ and Małgorzata Graczyk ${ }^{2}$ \\ 1 Department of Soil Science and Land Protection, Poznan University of Life Sciences, ul. Szydłowska 50, \\ 60-656 Poznań, Poland \\ 2 Department of Mathematical and Statistical Methods, Poznan University of Life Sciences, \\ ul. Wojska Polskiego 28, 60-637 Poznań, Poland; malgorzata.graczyk@up.poznan.pl \\ * Correspondence: monika.jakubus@up.poznan.pl
}

Received: 6 October 2020; Accepted: 13 November 2020; Published: 17 November 2020

check for updates

\begin{abstract}
This work presents quantitative changes of nickel in soil and plants under the influence of compost and fly ash. The research was carried out in a 3-year experiment on medium soil fertilised with compost or fly ash. The plants: narrow leaf lupine (Lupinus angustifolius L.), camelina (Camelina sativa L.), and oat (Avena sativa L.) were planted in consecutive years. The soil from the experiment was subjected to extraction by sequential analysis with the Community Bureau of Reference (BCR) method, and single extractions using $1 \mathrm{~mol} \cdot \mathrm{dm}^{-3} \mathrm{HCl}$ and DTPA solutions, obtaining the amount of nickel in various combinations with the soil solid phase. Total contents of the metal in soil and cultivated plants were determined. On the basis of Ni contents in the soil and cultivated plants, the bioconcentration factors and the risk assessment code were calculated. The type of amendments had a significant impact on the nickel content in lupine, for camelina and oat was the greatest in the control conditions. The differences between the amounts of Ni determined for bioconcentration factors were significant and depended on the amendments and nickel obtained by different methods. Regardless of the experimental conditions, the amount of $\mathrm{Ni}$ in the exchangeable bonds (Fr. I) had the greatest impact on the content of $\mathrm{Ni}$ in lupine and oat, whereas $\mathrm{Ni}_{\text {DTPA }}$ in the case of camelina.
\end{abstract}

Keywords: compost; fly ash; nickel fractions; bioconcentration factors; risk assessment code; agriculture; ANOVA; heatmap; multiple regression

\section{Introduction}

Nickel is an interesting element because it acts both as a toxic heavy metal and an essential microelement for plants. Nickel enters into the soil mainly through anthropogenic activities, such as mining, smelting, application of some organic amendments, e.g., sewage sludge or compost based on sewage sludge. Other sources of this element include solid fuel combustion, burning of diesel, and fuel oil, as well as ceramic, glass, metal, and chemical industries [1,2]. Both nickel toxicity and its requirement in plants are well-documented in literature, although more often studies focus on the negative effect of nickel on plants in the case of its excess amounts in soil. Ameen et al. [2], in their review paper, extensively presented these aspects. The cited authors indicated that exposure of plants to high levels of Ni usually results in several phytotoxic symptoms, such as chlorosis, necrosis, limited shoot and root growth, and reduced leaf area. Moreover, disturbance in the activity of various enzymes, initiation of oxidative stress, and interruption in uptake of other nutrients have also been documented [3]. Simultaneously, it is underlined that Ni is the central element of urease enzyme responsible for the hydrolysis of urea to ammonia. On the other hand, at low concentrations $\mathrm{Ni}$ has a positive effect on seed germination, growth of shoots, and roots, while it also improves fruit yield and 
quality, and promotes the synthesis of chlorophyll, protein, and carbohydrates in plant tissues [2,3]. Due to the fact that knowledge on the importance of nickel is not common, and its necessary amounts for plants are small, in the routine fertilisation of crops, it is not replenished as it is the case with $\mathrm{Cu}$, $\mathrm{Zn}, \mathrm{Mn}$, or B. Crops take up nickel easily, usually proportionally to its content in soil until the level of toxicity is reached [1]. Nickel is considered to be a mobile element and its availability is controlled by such factors as quantity and quality of clay minerals, organic matter, or soil reaction. In acid soils, $\mathrm{Ni}$ solubility increases considerably, and its sorption by Fe and Mn hydroxides increases with a decrease in acidity [4]. However, due to the susceptibility of nickel to form complexes with organic matter, in many soils its high mobility is maintained even under neutral conditions. This is due to the fact that $\mathrm{Ni}$ creates bonds with organic matter in the form of mobile chelates. Nickel availability for plants is significantly reduced in the case of liming soil or the use of high doses of phosphorus fertilisers [4,5]. Regardless of the type of soil and the applied fertiliser, information on the availability of the nutrients for plants is important for agricultural practice. There are many methods to achieve this goal. The bioavailability of metals in soil may be determined based on chemical methods, which include single and sequential extractions. Single methods (one-step analysis) are preferred for dissolving the phase, which element content is easily activated and perfectly correlates with its bioavailability. For this type of extraction, a number of chemical compounds can be used that differ in their mode of action and extraction strength [6-8]. The different character of analysis is associated with the sequential methods, which are used to provide insight into the processes that affect the availability of metals in soil. These extractions consist of acting on a soil sample with a series of reagents with increasing ionic strength to dissolve metal forms that are increasingly attached to the matrix. The sequentially isolated fractions of metals correspond to different types of metal complexes with the soil solid phase [9].

Referring to the promoted and implemented paradigm of the circular economy and the assumptions of the zero waste programme [10], it is proposed to use chosen processed wastes for fertilisation purposes. In this context, the importance of the composts prepared from various biowastes and fly ash is emphasised. Organic fertilisation is a method of substituting inorganic fertilisers with organic fertilisers and, thereby, improving general soil fertility. There are many papers [11-13] dealing with the benefits of composted biowaste in terms of their positive effect on physical, chemical, physico-chemical and biological properties, which consequently considerably improves soil fertility. In the case of the use of fly ash, the effect expressed by an increase in $\mathrm{pH}$ is indicated first of all. Additionally, the positive role in increasing the water holding capacity, as well as improving soil structure, is also emphasised [14]. Regardless of the positive aspects connected with the use of composts or fly ash, it should be taken into account that these amendments will influence the availability of nutrients, especially those in which mobility in soil will depend on the amount of organic matter and soil reaction changes. As previously mentioned, nickel is such an element and, therefore, in this work, the research was undertaken to determine the following goals:

1. Nickel availability assessment in soil in relation to used extractants and applied fertilisation;

2. Nickel accumulation in cultivated plants, depending on nickel availability and used fertilisation.

\section{Material and Methods}

\subsection{Experimental Design}

A 3-year (2014-2016) pot experiment was conducted at the experimental vegetation station belonging to the Wroclaw University of Life Sciences. Outdoor, natural conditions were provided for the experimental facility because it was covered with wire mesh. The medium agronomic soil class (clay loam), classified as Haplic Cambisols according to the World Reference Base for Soil Resources (WRB) [15] was used. The compost (a mixture of biowaste (collected separately) and manure, prepared in a 1:1 ratio by the aerobic technology of the composting process) used for experiments met the requirements set out in the respective Polish law [16], and was produced for commercial purposes by a local composting facility. Fly ash was formed as a by-product of lignite combustion in smoke 
ducts and was captured by detecting devices (electrostatic precipitators). It comes in the form of fine, mineral dust with a particle diameter of $0-100 \mu \mathrm{m}$, and a light grey colour. Fly ash is silicate-calcium ash and is characterised by an alkaline reaction.

Soil and compost were sieved through a $20 \mathrm{~mm}$ sieve before setting up the experiment. The basic properties of used soil, compost, and fly ash are presented in Table 1. The $\mathrm{pH}$ of compost and fly ash was assessed in $\mathrm{H}_{2} \mathrm{O}$ and in $1 \mathrm{~mol} \cdot \mathrm{dm}^{-3} \mathrm{KCl}$ for soil. The ratio soil/compost/fly ash: solution was 1:2.5 $(w / v)$. Total organic carbon (TOC) and total nitrogen (Ntot) contents in soil, compost and fly ash were assayed using a Vario Max CNS elemental analyser. The total amounts of nickel in compost and fly ash were assessed according to the aqua regia procedure [17].

Dry soil samples of $10 \mathrm{~kg}$ were weighed in eight replications and they were thoroughly mixed with the dose of compost as well as of fly ash two weeks before plant cultivation. The compost and fly ash were applied at a rate of $40 \mathrm{t} \cdot \mathrm{ha}^{-1}$ into the soil. Each mixture was wetted to $60 \%$ field capacity. The experiment was conducted in PVC pots $(10 \mathrm{~kg})$, and, as a result, the design of the experiment included: T0-control soil (without compost and fly ash addition) and T1-soil with the compost addition. TII-soil with the fly ash addition. Three crops, i.e., narrow leaf lupine (Lupinus angustifolius L.), camelina (Camelina sativa L.), and oat (Avena sativa L.), were planted in consecutive years (2014-2016) after harvesting in the same pot. The experiment was conducted at a density of 10 plants per pot. After harvesting of each plant from the pots soil samples for analysis were taken. Next the residue in the pots was cleaned of the remaining roots and the soil, while compost and ash were replenished. In this way, the next crop had the same growing conditions and the amounts of nickel in the substrate were theoretically always the same. Taking into account the nutritional requirements of plants adequate supplementing mineral fertilisation was applied. The applied doses of fertilizers were balanced in such a way that they took into account the amounts of N, P, K introduced with compost and fly ash.

\subsection{Analysis of Plant Materials}

Plant material was dried at $60^{\circ} \mathrm{C}$, and ground and ashed in a furnace at $450{ }^{\circ} \mathrm{C}$ for $6 \mathrm{~h}$. The ash was dissolved in $5 \mathrm{~mL}$ of $6 \mathrm{~mol} \cdot \mathrm{dm}^{3} \mathrm{HCl}$ and diluted to a constant volume with distilled water [18]. The obtained extracts were analysed to assess Ni contents using atomic absorption spectrophotometry (ASA) in a Varian Spectra AA 220 FS apparatus. All of the assays identifying the amounts of nutrients in the tested samples were performed in three replications.

Table 1. Basis properties of soil, compost and fly ash (data for composite sample).

\begin{tabular}{cccc}
\hline Parameter & Soil & Compost & Fly Ash \\
\hline $\mathrm{pH}$ & 7.0 & 6.8 & 13.7 \\
$\mathrm{TOC}\left(\mathrm{g} \cdot \mathrm{kg}^{-1}\right)$ & 16.8 & 181.3 & n.d. ${ }^{*}$ \\
$\mathrm{Ntot}\left(\mathrm{g} \cdot \mathrm{kg}^{-1}\right)$ & 1.8 & 2.7 & 0.5 \\
$\mathrm{Ni}\left(\mathrm{mg} \cdot \mathrm{kg}^{-1}\right)$ & 9.6 & 23.6 & 41.8 \\
\hline \multicolumn{4}{c}{ * n.d.-not determined. }
\end{tabular}

\subsection{Analysis of Soil}

The amounts of Ni in soil samples were determined using four different methods:

1. Total content with the aqua regia procedure [17] (TC);

2. Available amounts with the single extraction method using $1 \mathrm{~mol} \cdot \mathrm{dm}^{-3} \mathrm{HCl}[19]\left(\mathrm{Ni}_{\mathrm{HCl}}\right)$;

3. Bioavailable amounts with the single extraction method using DTPA complexing solution $\left(0.005 \mathrm{~mol} \cdot \mathrm{dm}^{-3} \mathrm{DTPA}+0.1 \mathrm{~mol} \cdot \mathrm{dm}^{-3} \mathrm{TEA}+0.01 \mathrm{~mol} \cdot \mathrm{dm}^{-3} \mathrm{CaCl}_{2}\right.$, at $\left.\mathrm{pH} 7.3\right)$ [20] $\left(\mathrm{Ni}_{\text {DTPA }}\right)$;

4. Sequential analysis with the Community Bureau of Reference (BCR) method [21]. The details of the experimental protocol are shown in Table 2. 
Concentrations of nickel in the extracts were determined by flame atomic absorption spectrometry (FAAS) using a Varian Spectra AA 220 FS apparatus.

On the basis of $\mathrm{Ni}$ contents in the soil and cultivated plants the bioconcentration factors (BCF) for nickel were calculated. The BCF is defined as the ratio of metal content in plant shoots to metal contents in soil. It is the theoretical ability of a plant to take up and transport metals to the harvestable aerial parts. Since in the presented work the various methods of nickel extraction were applied, showing different metal combinations with the soil solid phase and, thus, their bioavailability for plants, it was reasonable to include them in the calculation of BCF. In view of the above, the obtained amounts of nickel in sequentially separated fractions (I-IV) by BCR, the amounts of available, bioavailable, and total bioconcentration factors were calculated according to the following formulas:

$$
\begin{aligned}
\mathrm{BCF}_{\mathrm{T}} & =\frac{\text { metal in plant shoots }}{\text { total metal content }} \\
\mathrm{BCF}_{\mathrm{A}} & =\frac{\text { metal in plant shoots }}{\text { available metal amount }} \\
\mathrm{BCF}_{\mathrm{B}} & =\frac{\text { metal in plant shoots }}{\text { bioavailable metal amount }} \\
\mathrm{BCF}_{\mathrm{I}} & =\frac{\text { metal in plant shoots }}{\text { metal amount in FR I }} \\
\mathrm{BCF}_{\mathrm{II}} & =\frac{\text { metal in plant shoots }}{\text { metal amount in FR II }} \\
\mathrm{BCF}_{\mathrm{III}} & =\frac{\text { metal in plant shoots }}{\text { metal amount in FR III }} \\
\mathrm{BCF}_{\mathrm{IV}} & =\frac{\text { metal in plant shoots }}{\text { metal amount in FR IV }}
\end{aligned}
$$

Additionally the risk assessment code (RAC) was calculated. RAC expresses a percentage share of metals present in the exchangeable fraction (Fr. I) in its total content [22]. RAC grades the environmental risk into the five classes as follows:

\begin{tabular}{|c|c|c|c|}
\hline \multirow{2}{*}{ Fraction } & \multirow{2}{*}{ Extracting Agent } & \multicolumn{2}{|c|}{ Extractions Conditions } \\
\hline & & Time & Temperature \\
\hline Fr. I-Exchangeable & $\begin{array}{c}0.11 \mathrm{~mol} \cdot \mathrm{dm}^{-3} \mathrm{CH}_{3} \mathrm{COOH} \\
(\mathrm{pH}=7.0)\end{array}$ & $16 \mathrm{~h}$ & $20-25^{\circ} \mathrm{C}$ \\
\hline $\begin{array}{l}\text { Fr. II-Reducible (metals bound to } \\
\text { Fe and Mn oxides) }\end{array}$ & $\begin{array}{c}0.5 \mathrm{~mol} \cdot \mathrm{dm}^{-3} \mathrm{NH}_{2} \mathrm{OH}-\mathrm{HCl} \\
(\mathrm{pH}=1.5)\end{array}$ & $16 \mathrm{~h}$ & $20-25^{\circ} \mathrm{C}$ \\
\hline $\begin{array}{l}\text { Fr. III-Oxidisable (metals bound } \\
\text { to organic matter and sulphides) }\end{array}$ & $\begin{array}{c}30 \% \mathrm{H}_{2} \mathrm{O}_{2}(\mathrm{pH}=2.0) \text { and then } \\
1.0 \mathrm{~mol} \cdot \mathrm{dm}^{-3} \mathrm{CH}_{3} \mathrm{COONH}_{4} \\
(\mathrm{pH}=2.0)\end{array}$ & $\begin{array}{l}1,2 \\
16 \mathrm{~h}\end{array}$ & $20-25,85,20-25^{\circ} \mathrm{C}$ \\
\hline Fr. IV-Residual & Aqua regia & $2.5 \mathrm{~h}$ & $60-70^{\circ} \mathrm{C}$ \\
\hline
\end{tabular}

RAC $<1 \%$-no risk (safe to the environment);

RAC $1-10 \%$-low risk (relatively safe to the environment);

RAC $11-30 \%$-medium risk (relatively dangerous to the environment);

RAC 31-50\%-high risk (dangerous to the environment);

RAC $>50 \%$-very high risk (very dangerous to the environment).

Table 2. Community Bureau of Reference (BCR) sequential extraction procedure [21].

\subsection{Statistical Analysis}

In order to compare Ni contents in sequentially separated fractions (I-IV), the amounts of available, bioavailable and total $\mathrm{Ni}$, depending on the experimental conditions (T0, TI, TII) and for comparing $\mathrm{Ni}$ contents in cultivated plants, the violin plots were made.

For the amounts of nickel in sequentially separated fractions, the amounts available, bioavailable and total Ni we used one-way ANOVA to compare the average Ni contents between soils with different 
amendments (T0, TI, TII) and determine whether any of those means are statistically significantly different from each other according to the model

$$
y_{i j}^{k}=\mu_{i}^{k}+e_{i j^{\prime}}^{k}
$$

where $y_{i j}^{k}$ is the content of $k$ th form of $\mathrm{Ni}$, in $j$ th experimental unit for $i$ th treatment, $\mu_{i}^{k}$ is mean for $i$ th treatment and for $k$ th Ni type, $k \in\{\mathrm{HCl}$, DTPA, Fr. I, Fr. II, Fr. III, Fr. IV, TC $\}, i \in\{$ T0, TI, TII $\} . e_{i j}^{k}$ is experimental error. Thus, we study the hypothesis $\mathrm{H}_{0}: \mu_{\mathrm{T} 0}^{k}=\mu_{\mathrm{TI}}^{k}=\mu_{\mathrm{TII}}^{k}$. In order to show the differences between the groups, the confidence intervals were presented.

Separately for each plant, we compared Ni contents between soil with different additions and determined whether any of those means are statistically significantly different from each other, according to the model

$$
y_{i j}^{s}=\mu_{i}^{s}+e_{i j}^{s}
$$

where $y_{i j}^{s}$ is Ni content in sth plant, in $j$ th experimental unit for ith treatment, $\mu_{i}^{s}$ is mean for $i$ th treatment and $e_{i j}^{s}$ is experimental error, $s \in\{$ Lupine, Camelina, Oat $\}$. Thus, we study the hypothesis $\mathrm{H}_{0}: \mu_{\mathrm{T} 0}^{s}=\mu_{\mathrm{TI}}^{s}=\mu_{\mathrm{TII}}^{s}$. To determine the differences between the groups, the confidence intervals were given.

To present the hierarchical relationship between sequentially separated fractions, the amounts available, bioavailable, and total $\mathrm{Ni}$ within each soil, the dendrograms were made.

According to the character of the experiment, we studied bioconcentration factors for each plant separately. The two-way ANOVA was used to verify statistically significant differences in the bioconcentration factors determined for the investigated plants. The statistical analysis of the effects of the main factors under study (amendment and Ni forms), as well as the interaction between them, was conducted on the linear model with interaction

$$
y_{i j k}^{s}=\mu^{s}+\alpha_{i}^{s}+\tau_{j}^{s}+(\alpha \tau)_{i j}^{s}+e_{i j k}^{s}
$$

where $y_{i j k}^{s}$ is the bioconcentration factor of $k$ th Ni type, in $j$ th experimental unit for ith treatment, $\mu^{s}$ is the general mean for sth plant, $\alpha_{i}^{s}$ is the effect of $i$ th treatment for sth plant, $\tau_{j}^{s}$ is the effect of $j$ th experimental unit in sth plant, $(\alpha \tau)_{i j}^{s}$ denotes the interaction and $e_{i j k}^{s}$ is the is the random error of experimental factors. Because the interaction was significant, the homogeneous groups were determined as the next step of post hoc analysis.

Next, in order to show the relationships between sequentially separated fractions, the amounts available, bioavailable and total $\mathrm{Ni}$ determined for bioconcentration factor within each soil and for each plant the heatmaps were made.

Subsequently, to describe the relationships between various forms $\mathrm{Ni}$, separately for each amendment in soil and for each plant, multiple regression was determined according to the model

$$
y^{i s}=b_{0}^{i s}+\sum_{k} b_{t k}^{i s} x_{k}^{i s}
$$

where $y_{i s}$ is the response variable, i.e., $\mathrm{Ni}$ content in sth plant in ith experimental conditions, $x_{i s k}$ predictor variables $\left(\mathrm{HCl}, \mathrm{DTPA}\right.$, Fr. I, Fr. II, Fr. III, Fr. IV, TC), $b_{i t 0}$ intercept, $b_{t k}^{i s}$ regression coefficients, $t=1,2, \ldots, 7$. The measure of matching multiple regression to data is the factor $\mathrm{R}^{2}$, which is the proportion of variance in the dependent variable that can be explained by the independent variables. Analysis of the data was performed using the package $\mathrm{R}$ for $\alpha=0.05$.

According to the character of the pot experiment and performed chemical analyses for individual samples, there was obtained a set of twenty four data for each treatment. The data were calculated using the package $\mathrm{R}$ for $\alpha=0.05$. 


\section{Results}

\subsection{Nickel in Soil}

The applied amendments as well as their lack had no effect on the content of Ni extracted by DTPA ( $p$-value $=0.8268)$ giving average values of $0.65-0.70 \mathrm{mg} \cdot \mathrm{kg}^{-1}$ (Figures 1 and 2$)$. The contents of $\mathrm{Ni}_{\mathrm{HCl}}$ obtained for soil representing the TI and TII treatments did not differ significantly. The amount of $\mathrm{Ni}$ available in the soil with the compost addition was on average $4.05 \mathrm{mg} \cdot \mathrm{kg}^{-1}$, whereas in the soil with the fly ash $4.16 \mathrm{mg} \cdot \mathrm{kg}^{-1}$. At the same time these values were significantly higher in comparison to $\mathrm{Ni}_{\mathrm{HCl}}$ contents found in the control conditions $\left(3.57 \mathrm{mg} \cdot \mathrm{kg}^{-1}\right)\left(p\right.$-value $=5.29 \times 10^{-6}$, Figures 1 and 2).

The same tendency was observed in the case of Ni contents in Fr. II. The Ni content in the reducible fraction assessed for the soil enriched with compost was on average $2.27 \mathrm{mg} \cdot \mathrm{kg}^{-1}$, and for the soil with the fly ash addition, it amounted to $2.21 \mathrm{mg} \cdot \mathrm{kg}^{-1}, p$-value $=0.0229$. These metal contents were significantly higher in relation to the Ni amount in Fr. II in the control $\left(1.83 \mathrm{mg} \cdot \mathrm{kg}^{-1}\right)$, see Figures 1 and 2.

The highest Ni content in Fr. I was recorded in the case of soil amendment with compost and was average $1.08 \mathrm{mg} \cdot \mathrm{kg}^{-1}$. It was significantly different from Ni contents in Fr. I found for soil from the T0 and TII treatments, for which no differences were noted $\left(0.90 \mathrm{mg} \cdot \mathrm{kg}^{-1}\right.$ in $\mathrm{T} 0,0.89 \mathrm{mg} \cdot \mathrm{kg}^{-1}$ in TII) $(p$-value $=0.00575$, Figures 1 and 2$)$.

The applied amendments did not significantly influence Ni amounts in Fr. III, $p$-value $=0.012$ (with the average value in the case of compost addition $3.03 \mathrm{mg} \cdot \mathrm{kg}^{-1}$ and $3.24 \mathrm{mg} \cdot \mathrm{kg}^{-1}$ in the case of fly ash addition). Simultaneously these amounts were smaller in comparison to the values obtained for the control soil (the average value 3.42) (Figures 1 and 2).

The Ni content obtained in Fr. IV was the highest in the soil enriched with fly ash (average value $8.16 \mathrm{mg} \cdot \mathrm{kg}^{-1}$ ) and it was slightly greater than that obtained in the soil enriched with compost at $7.23 \mathrm{mg} \cdot \mathrm{kg}^{-1}$. The average Ni total content obtained in the control was the lowest and amounted to $9.66 \mathrm{mg} \cdot \mathrm{kg}^{-1}$ ( $p$-value $<2 \times 10^{-16}$, Figures 1 and 2$)$.

The total Ni content depends on the application of additions ( $p$-value $\left.<2 \times 10^{-16}\right)$. The highest total Ni contents $\left(14.32 \mathrm{mg} \cdot \mathrm{kg}^{-1}\right)$ was recorded in the soil enriched with fly ash and it was slightly higher in comparison to the soil amended with compost addition $\left(13.35 \mathrm{mg} \cdot \mathrm{kg}^{-1}\right)$. The significantly smallest value of Ni content in Fr. IV was noted in the soil without additions (average value $4.12 \mathrm{mg} \cdot \mathrm{kg}^{-1}$ ) (Figures 1 and 2).

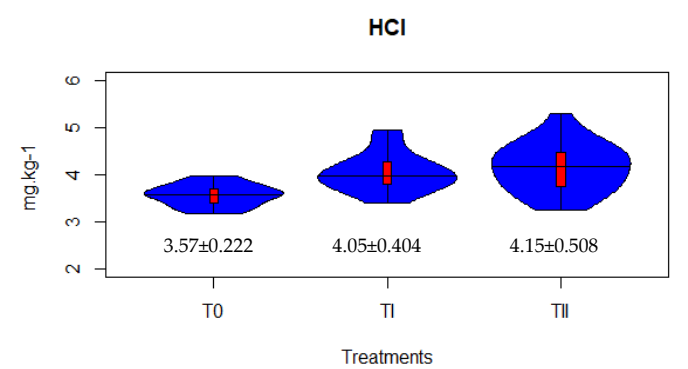

FR I

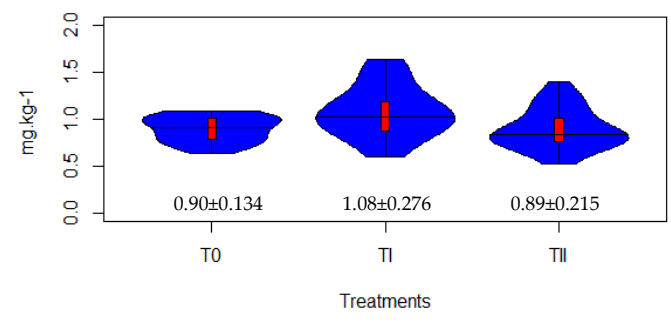

DTPA

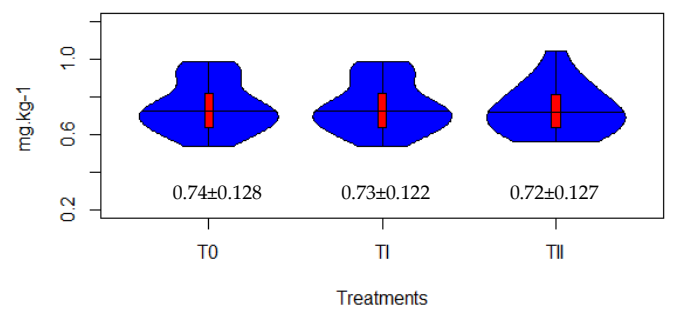

FR II

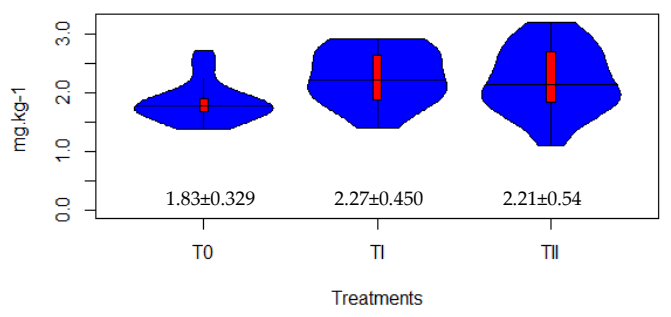

Figure 1. Cont. 

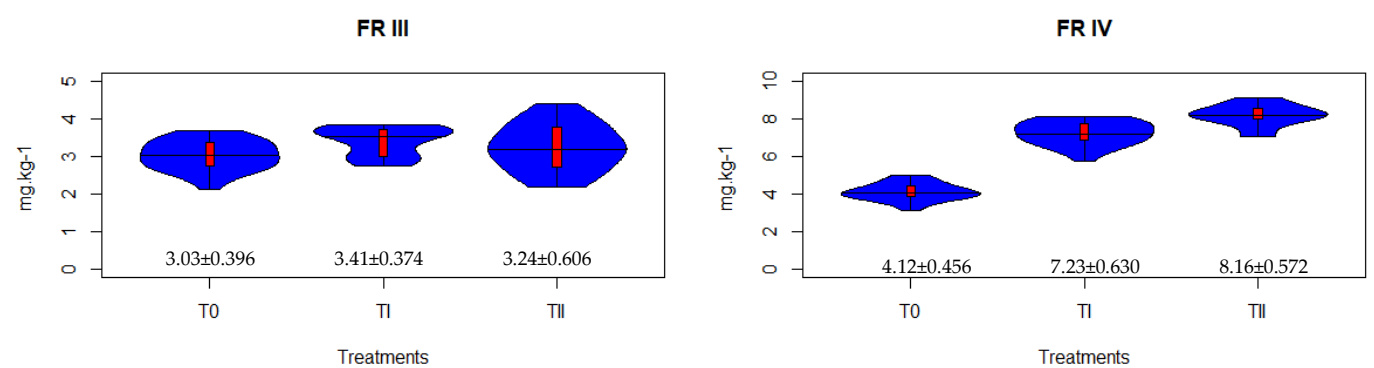

TC

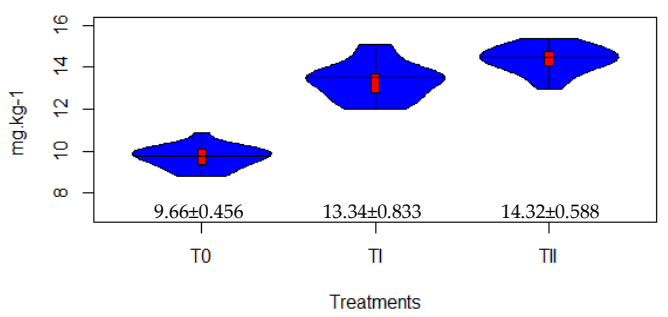

Figure 1. The nickel amounts in soil in dependence on treatments (T0, TI, TII) and used extractant. The values below the graphs are equal mean $\pm \mathrm{sd}$.
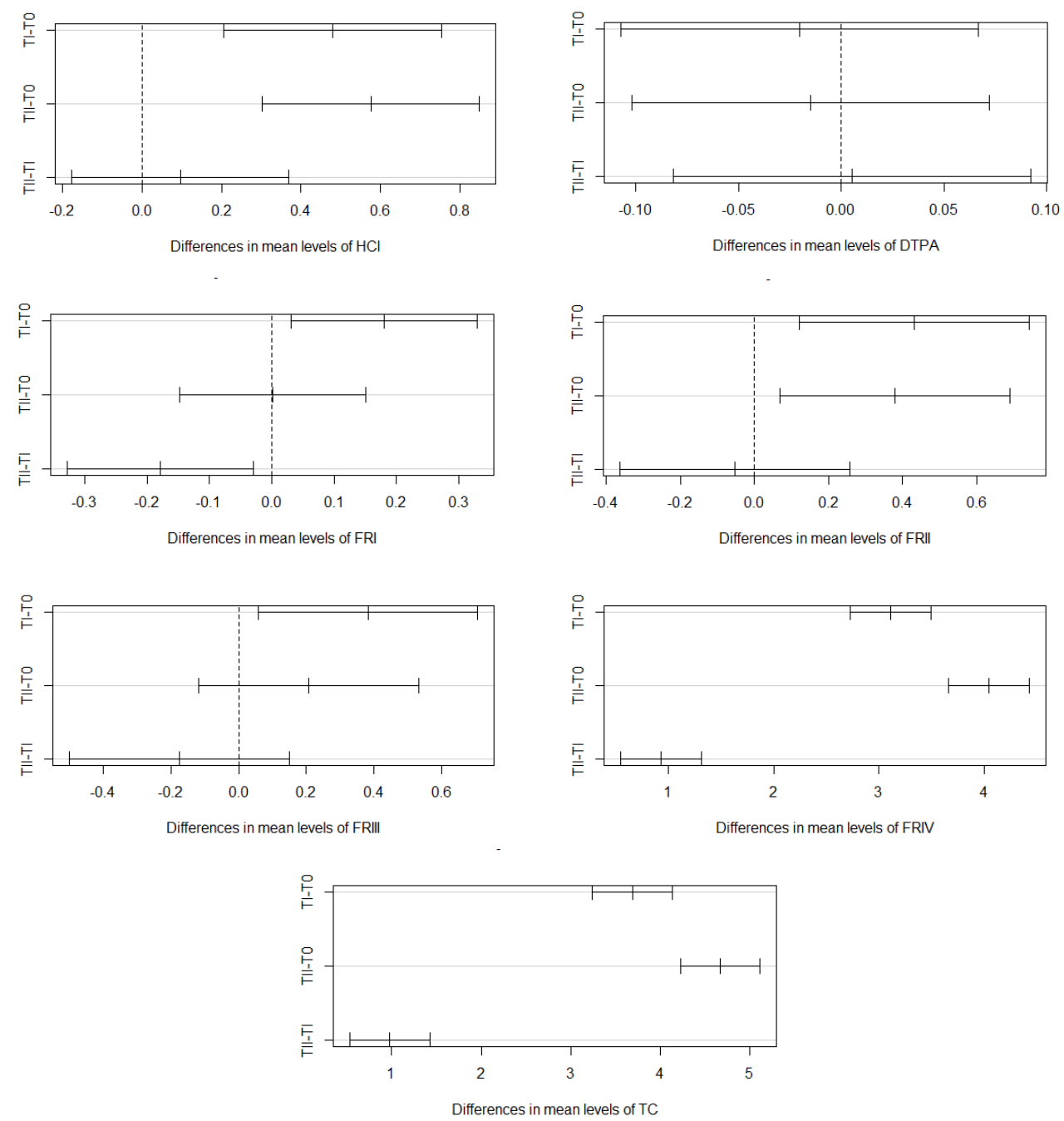

Figure 2. The $95 \%$ family-wise confidence levels for nickel amounts in soil in dependence on treatments (T0, TI, TII) and used extractant. 
Moreover, for the soils considered in the experiment, the dendrograms were determined (Figure 3). The dendrograms present the division into homogeneous groups according to the experimental conditions. Regardless of the applied amendments or their lack, the amounts of bioavailable $\mathrm{Ni}$ and $\mathrm{Ni}$ in Fr. I were the most comparable. Furthermore, the most similar contents were obtained for $\mathrm{Ni}$ in Fr. III and Fr. IV in the control soil. In the case of compost application the most similar amounts of $\mathrm{Ni}$ were obtained for Fr. II and Fr. III. Moreover, comparable values of $\mathrm{Ni}$ were observed for $\mathrm{Ni}$ in Fr. IV and the total metal content. In addition, the most similar amount of $\mathrm{Ni}$ was found for $\mathrm{Ni}$ in Fr. IV and for its total content in the soil with fly ash addition. Concomitantly, similar values of metal contents were observed for $\mathrm{Ni}$ in $\mathrm{Fr}$. III and $\mathrm{Ni}_{\mathrm{HCl}}$. Of all the nickel forms considered under various experimental conditions, the highest amount of this element was recorded for total $\mathrm{Ni}$.

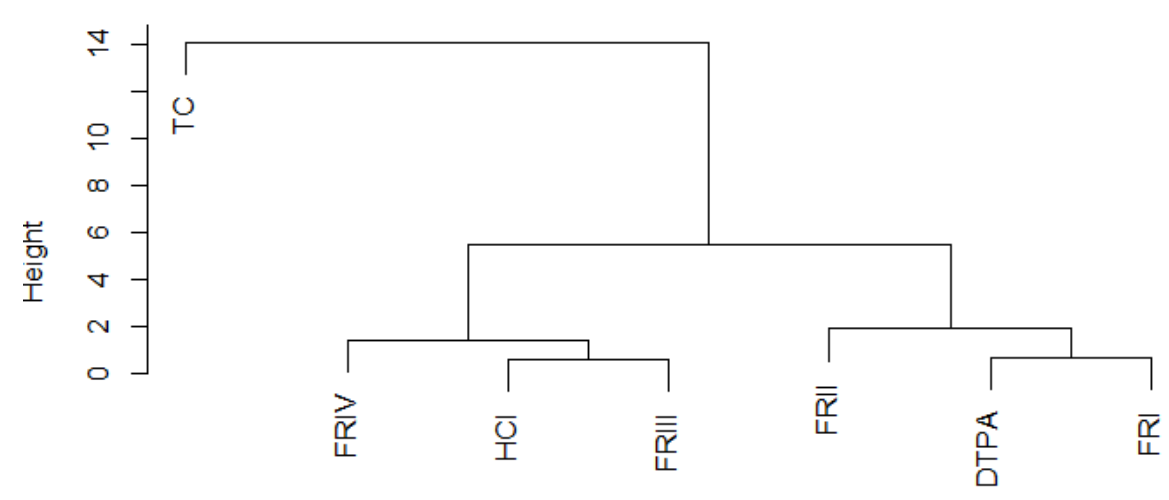

TI

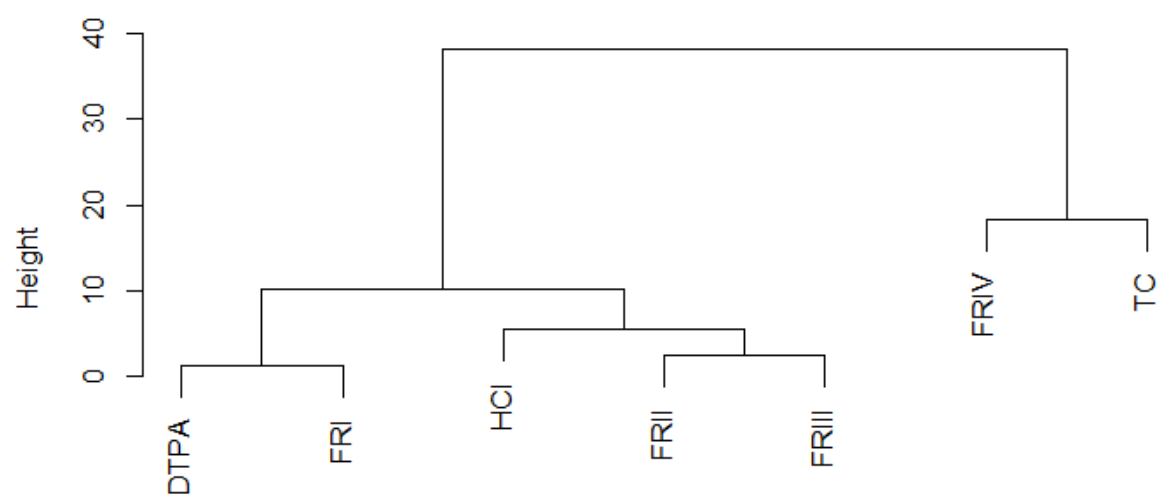

TII

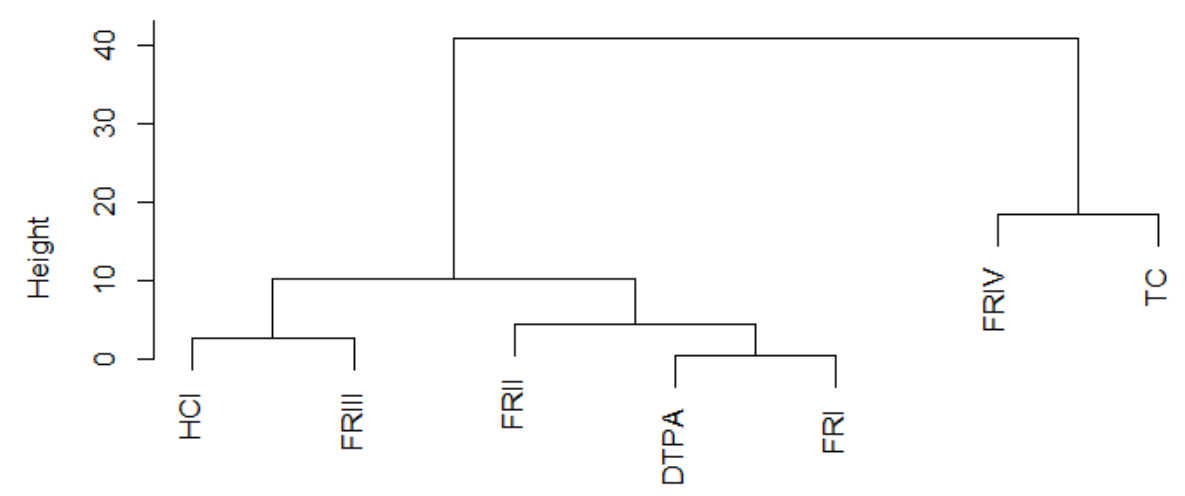

Figure 3. The nickel amounts in soil (T0, TI, TII) in dependence on used extractant. 


\subsection{Nickel in Plants}

The type of additives used had a highly significant impact on the nickel content in lupine $\left(p\right.$-value $\left.=5.86 \times 10^{-6}\right)$. The highest Ni contents were recorded for plants growing in the soil with fly ash (average value $9.00 \mathrm{mg} \cdot \mathrm{kg}^{-1}$ ) and they were significantly higher than those determined for plants growing in the soil amended with compost (average value $7.39 \mathrm{mg} \cdot \mathrm{kg}^{-1}$ ). The lowest Ni content in the case of lupine was observed for plants in the control conditions (average value $5.87 \mathrm{mg} \cdot \mathrm{kg}^{-1}$ ) (Figures 4 and 5).

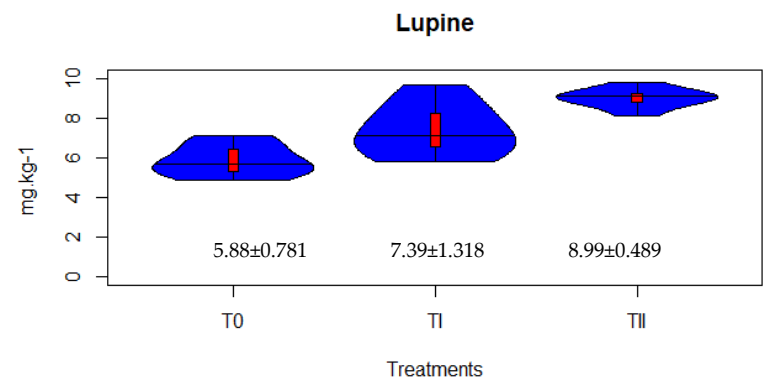

Camelina

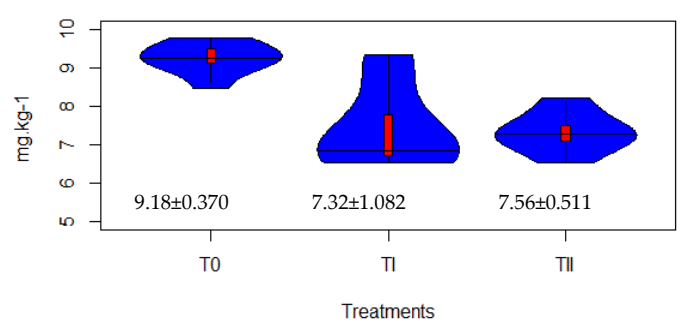

Oat

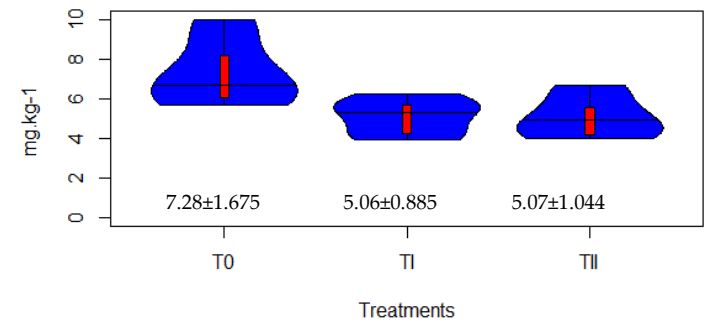

Figure 4. The nickel amounts in cultivated plants (lupine, camelina, oat) in dependence on treatments (T0, TI, TII). The values below the graphs are equal mean $\pm \mathrm{sd}$.
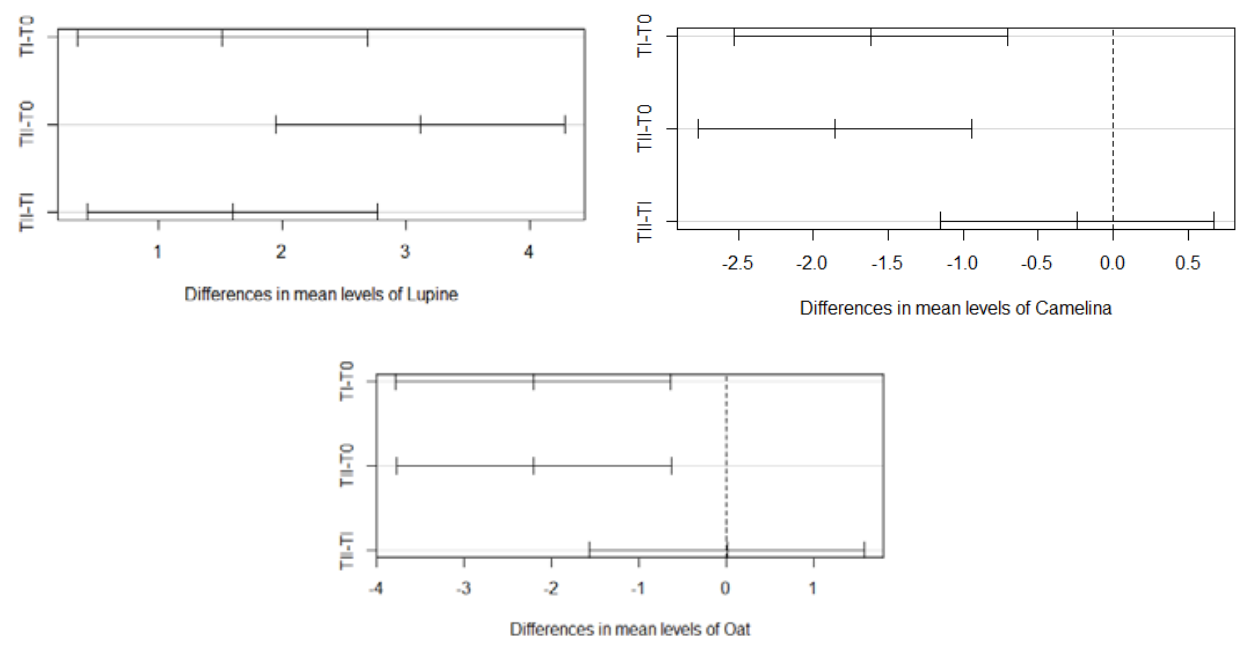

Figure 5. The 95\% family-wise confidence levels for nickel amounts in cultivated plants (lupine, camelina, and oat) in dependence on treatments (T0, TI, TII).

For plants grown in subsequent years, i.e., for camelina and oat, the Ni contents observed in the control conditions were greater than those recorded in plants growing in the soils with fly ash or compost addition ( $p$-value $=7.05 \times 10^{-5}$ and $p$-value $=0.00216$, respectively). The Ni content obtained for camelina in the control conditions was on average $9.17 \mathrm{mg} \cdot \mathrm{kg}^{-1}$, while for oat it was $7.27 \mathrm{mg} \cdot \mathrm{kg}^{-1}$. The type of additions used did not affect the level of $\mathrm{Ni}$ in camelina, because plants cultivated in soil 
amended with compost showed the average value of $7.55 \mathrm{mg} \cdot \mathrm{kg}^{-1}$, whereas in the soil enriched in fly ash the average value was $7.32 \mathrm{mg} \cdot \mathrm{kg}^{-1}$ (Figures 4 and 5). A similar tendency was observed in the case of oat. The Ni content in plants growing in the soil with compost addition was, on average, $5.065 \mathrm{mg} \cdot \mathrm{kg}^{-1}$, and on the soil with fly ash application it was $5.07 \mathrm{mg} \cdot \mathrm{kg}^{-1}$ (Figures 4 and 5).

\subsection{Bioconcentration}

For the bioconcentration factors, the analysis of variance was conducted for the experiment with two factors, the first one: type of amendment (control soil: T0, soil with compost addition: TI, soil with fly ash addition: TII), the second one: amounts of nickel obtained by different methods (separated fractions by BCR as well as the available, bioavailable and total amounts). Independently of the cultivated plant and the applied amendments, the highest values of bioconcentration factors were found for DTPA (7.9-11.0). Slightly smaller values of BCF were determined for Fr. I (6.2-8.5) and Fr. II (2.8-3.9). The smallest (0.5-1.4), comparable values were shown by $\mathrm{BCF}_{\mathrm{T}}$ and $\mathrm{BCF}_{\mathrm{IV}}$ creating the same homogeneous group. A similar situation was observed in the case of $\mathrm{BCF}_{\mathrm{III}}$ and $\mathrm{BCF}_{\mathrm{A}}(1.5-2.5)$ being in the same homogeneous group. The differences between the amount of $\mathrm{Ni}$ determined for bioconcentration factors in lupine, camelina and oat were significant ( $p$-value $<2 \times 10^{-14}$, $p$-value $<2 \times 10^{-16}, p$-value $<2 \times 10^{-15}$ respectively). Therefore, the homogeneous groups were determined for each plant separately. Although the values of the bioconcentration factors differed between plants, they were included in the same homogeneous groups evaluated for each plant as follows: $\mathrm{BCF}_{\mathrm{B}}$ a, $\mathrm{BCF}_{\mathrm{I}} \mathrm{b}, \mathrm{BCF}_{\mathrm{II}} \mathrm{c}, \mathrm{BCF}_{\mathrm{III}} \mathrm{d}, \mathrm{BCF}_{\mathrm{A}} \mathrm{d}, \mathrm{BCF}_{\mathrm{IV}} \mathrm{e}, \mathrm{BCF}_{\mathrm{T}}$ (for T0, TI, and TII).

As the next step, heat maps were determined for the bioconcentration factors for plants (Figure 6). For particularly plants the heat map shows the bioconcentration factor values for the plants cultivated in the soil without (T0) or with amendments (TI and TII). The dendrograms along the sides show how the variables: T0, TI, and TII, are independently clustered and how the variables: $\mathrm{BCF}_{\mathrm{B}}, \mathrm{BCF}_{\mathrm{I}}, \mathrm{BCF}_{\mathrm{II}}$, $\mathrm{BCF}_{\mathrm{III}}, \mathrm{BCF}_{\mathrm{A}}, \mathrm{BCF}_{\mathrm{IV}}, \mathrm{BCF}_{\mathrm{T}}$, are independently clustered. Any pattern in the heat map indicates an association between used amendments in soils and the bioconcentration factor values. The division into homogeneous groups due to bioconcentration factors for camelina and oat was similar and it reflects the dependencies determined by ANOVA.

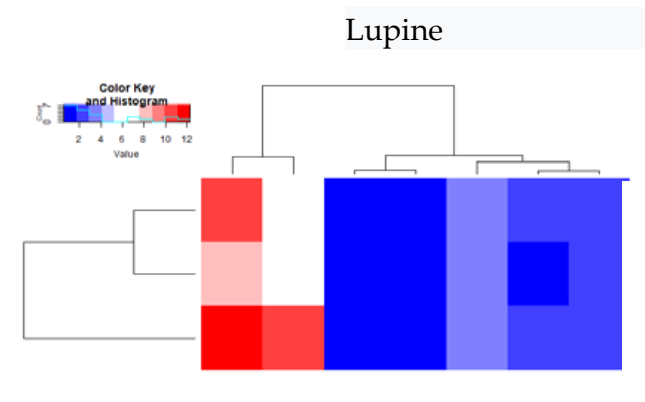

$\begin{array}{llllllll}\mathrm{BCF}_{\mathrm{B}} & \mathrm{BCF} & \mathrm{BCF}_{\mathrm{N}} & \mathrm{BCF}_{\mathrm{T}} & \mathrm{BCF}_{\mathrm{II}} & \mathrm{BCF}_{\mathrm{A}} & \mathrm{BCF}_{\mathrm{Il}}\end{array}$

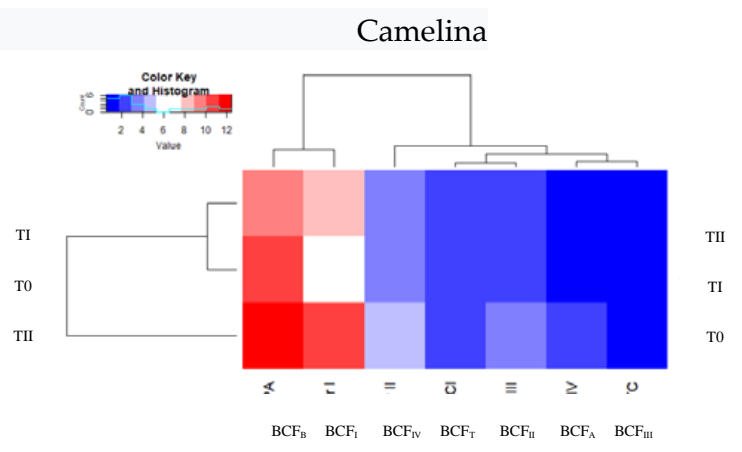

Oat

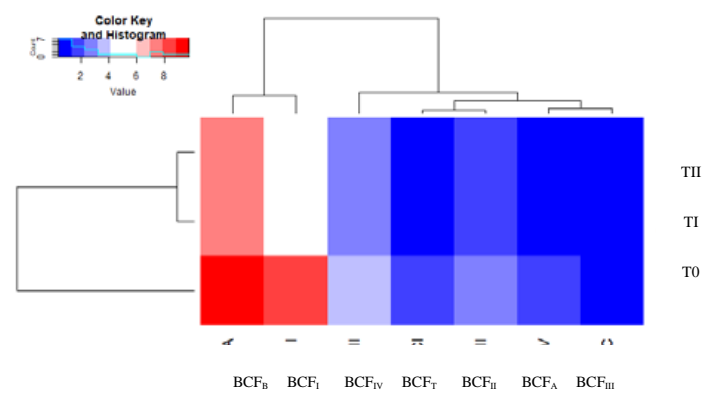

Figure 6. The heat maps for the nickel bioconcentration in cultivated plants (lupine, camelina, and oat) in dependence on treatments (T0, TI, TII). 
The influence of compost and fly ash on BCF values was similar for camelina and oat. In both cases the values of BCF were comparable for TI and TII and these values were significantly lower in comparison to those obtained in the control. For lupine, the highest values of BCF were found in the case of fly ash addition and the lowest in the control.

\subsection{Nickel in Soil and in Plants}

Multiple regression was used to determine the linear relationship between Ni content in soil determined by different methods and its amount in plants. After determining the multiple regression equation and obtaining the characteristics of the regression coefficients, multiple regression equations were determined for these variables that have a significant impact on the content of $\mathrm{Ni}$ in plant. The best-fit multiple regression equations for the data being analysed are given in Table 3 .

Table 3. Multiple regression equations for the relations between $\mathrm{Ni}$ content in plants and in $\mathrm{Ni}$ forms for soil treatments.

\begin{tabular}{|c|c|c|c|}
\hline Plant & Treatment & Equation & $R^{2}$ \\
\hline \multirow[t]{3}{*}{ Lupine } & T0 & $\mathrm{Ni}$ plant $=-31.71+10.06 \cdot \mathrm{Ni}_{\mathrm{Fr} . \mathrm{I}}+3.35 \cdot \mathrm{FR} \mathrm{III}+1.73 \cdot \mathrm{TC}$ & 0.56 \\
\hline & TI & $\mathrm{Ni}$ plant $=2.78+3.61 \cdot \mathrm{Ni}_{\mathrm{Fr} . \mathrm{I}}+1.03 \mathrm{Ni}_{\mathrm{Fr} . \mathrm{III}}$ & 0.61 \\
\hline & TII & $\mathrm{Ni}$ plant $=2.84+2.85 \cdot \mathrm{Ni}_{\mathrm{Fr} . \mathrm{I}}+0.97 \mathrm{Ni}_{\mathrm{Fr} . \mathrm{III}}$ & 0.59 \\
\hline \multirow[t]{3}{*}{ Camelina } & T0 & Ni plant $=-1.53+5.34 \cdot \mathrm{Ni}_{\mathrm{DTPA}}+3.02 \cdot \mathrm{Ni}_{\mathrm{Fr.I}}+1.23 \mathrm{Ni}_{\mathrm{Fr} . \mathrm{III}}$ & 0.62 \\
\hline & TI & $\mathrm{Ni}$ plant $=6.74+3.08 \cdot \mathrm{Ni}_{\mathrm{DPTA}}+1.48 \mathrm{Ni}_{\mathrm{Fr.I}}+0.21 \cdot \mathrm{Ni}_{\mathrm{Fr} . \mathrm{II}}$ & 0.60 \\
\hline & TII & Ni plant $=5.86+2.17 \cdot \mathrm{Ni}_{\mathrm{DTPA}}+0.15 \mathrm{Ni}_{\mathrm{Fr} . \mathrm{I}}$ & 0.53 \\
\hline \multirow[t]{3}{*}{ Oat } & T0 & $\mathrm{Ni}$ plant $=-3.278+3.58 \mathrm{Ni}_{\mathrm{Fr} . \mathrm{I}}+1.96 \cdot \mathrm{Ni}_{\mathrm{Fr} . \mathrm{III}}+0.11 \cdot \mathrm{TC}$ & 0.57 \\
\hline & TI & Ni plant $=-1.18+2.53 \mathrm{Ni}_{\mathrm{Fr} . \mathrm{I}}+1.34 \mathrm{Ni}_{\mathrm{Fr} . \mathrm{III}}$ & 0.61 \\
\hline & TII & $\mathrm{Ni}$ plant $=-2.02+3.12 \cdot \mathrm{Ni}_{\mathrm{Fr} . \mathrm{I}}+0.81 \cdot \mathrm{Ni} \mathrm{DPTA}+0.33 \cdot \mathrm{TC}$ & 0.59 \\
\hline
\end{tabular}

Regardless of the experimental conditions, the amount of Ni in Fr. I had the greatest impact on the content of $\mathrm{Ni}$ in lupine. It was expressed by the equation given in Table 3. It may be observed that if $\mathrm{Ni}$ content in Fr. I in the control soil increases by $1 \mathrm{mg} \cdot \mathrm{kg}^{-1}$, then $\mathrm{Ni}$ in the plant will increase by $10.06 \mathrm{mg} \cdot \mathrm{kg}^{-1}$. In the case of soil enriched with compost, $\mathrm{Ni}$ in lupine will increase by $3.61 \mathrm{mg} \cdot \mathrm{kg}^{-1}$ if the metal content in Fr. I increases by $1 \mathrm{mg} \cdot \mathrm{kg}^{-1}$. On the other hand, if in the soil amended with fly ash the Ni content in Fr. I increases by $1 \mathrm{mg} \cdot \mathrm{kg}^{-1}$, then $\mathrm{Ni}$ in the plant will increase by $2.85 \mathrm{mg} \cdot \mathrm{kg}^{-1}$.

Regardless of the experimental conditions, $\mathrm{Ni}_{\text {DTPA }}$ had the greatest impact on the content of $\mathrm{Ni}$ in camelina. According to data at Table 3, Ni in plants cultivated in the control soil will increase by $5.34 \mathrm{mg} \cdot \mathrm{kg}^{-1}$ if the bioavailable amount of $\mathrm{Ni}$ increases by $1 \mathrm{mg} \cdot \mathrm{kg}^{-1}$. When in the soil with compost addition $\mathrm{Ni}_{(\mathrm{DTPA})}$ increases by $1 \mathrm{mg} \cdot \mathrm{kg}^{-1}$, then in the plant it will increase by $3.08 \mathrm{mg} \cdot \mathrm{kg}^{-1}$. In camelina cultivated in the soil with fly ash addition, the $\mathrm{Ni}$ amount will increase by $2.17 \mathrm{mg} \cdot \mathrm{kg}^{-1}$, the amount of Ni extracted by DTPA increases by $1 \mathrm{mg} \cdot \mathrm{kg}^{-1}$.

Similarly, as in the case of lupine, the Ni amount in oat was determined first of all by the metal content in Fr. I, and it was dependent on the application of individual additions or their lack (Table 3). If in the control conditions, the Ni content in Fr. I increases by $1 \mathrm{mg} \cdot \mathrm{kg}^{-1}$ then $\mathrm{Ni}$ in the plant will increase by $3.58 \mathrm{mg} \cdot \mathrm{kg}^{-1}$. In the case of soil amended with compost, $\mathrm{Ni}$ in plants will increase by $2.53 \mathrm{mg} \cdot \mathrm{kg}^{-1}$ if the Ni content in Fr. I increases by $1 \mathrm{mg} \cdot \mathrm{kg}^{-1}$. When the Ni content in Fr. I in soil enriched with fly ash increases by $1 \mathrm{mg} \cdot \mathrm{kg}^{-1}, \mathrm{Ni}$ in oat will increase by $3.12 \mathrm{mg} \cdot \mathrm{kg}^{-1}$. 


\section{Discussion}

\subsection{Nickel in Soil}

The typical application of compost and/or fly ash is associated with remediation processes for soils contaminated with heavy metals [5,23-25]. The primary objective of such amendments in contaminated sites is to reduce metal mobility and bioavailability by their in situ immobilisation. However, when using compost or fly ash, one should primarily view these products as a source of organic matter and nutrients (composts) and a form of lime (fly ash). Without excluding their role as stabilising substances, their purely fertilising advantages should also be taken into account. In relation to the above, the effect of both substances on changes in nickel mobility in the aspect of its bioavailability for plants should be interpreted in two terms, i.e., sharing and limiting as evidenced by the results obtained in this study. Both compost and fly ash added to the soil caused an increase in the amounts of total, available, and sequentially separated fractions of Ni compared to the control. The exception were bioavailable amounts, which, regardless of fertilisation, did not differ statistically (Figures 1 and 2). The lack of the effect of used amendments on Ni extracted with DTPA is unusual, so more literature sources indicate it. Shahbaz et al. [8] found a reduction in the amount of Ni obtained with DTPA solution after the introduction of biochar, gravel sewage, and zeolite. According to those authors, it was related to nickel precipitation and reduction of its solubility in soil, and it was due to the rise in soil pH after the application of alkali amendments. Moreover, Cioccio et al. [5], after dolomitic limestone addition, found a considerable decrease of the plant available $\mathrm{Ni}$ in soil as a result of elevating soil $\mathrm{pH}$ and increased free metal ion complexation to clay and organic matter. It should be noted that DTPA solution, among all the used reagents, extracted the smallest amounts of $\mathrm{Ni}\left(0.65-0.70 \mathrm{mg} \cdot \mathrm{kg}^{-1}\right)$, which in relation to the metal total contents ranged from $4.8,4.9$ to $7.2 \%$ for soil of TI, TII, and T0, respectively. Despite the lack of the statistically confirmed effect of the used amendments on the bioavailable amounts of $\mathrm{Ni}$ in soil, the quoted percentage values, distinctly lower in the soil fertilised with both compost and fly ash indicate the immobilising role of applied amendments. It can be assumed that these mechanisms were the result of complexation by the functional groups of compost organic matter through the adsorption reaction and precipitation of nickel compounds caused by the increase in $\mathrm{pH}$. The percentage of Ni obtained by DTPA in relation to the total amount of the metal in soil is comparable to that reported by Luo et al. [26]. The amounts obtained with the DTPA solution in the presented study were comparable to those obtained with the acetic acid solution in the BCR method and described as Fr. I (the exchangeable bonds of Ni) (Figure 3), and it was independently of the applied additions or their lack. These results may indicate a similar pool of extracted nutrients constituting the mobile and easily accessible forms for plants. It is connected with the fact that the DTPA compounds form a complex with the extracted metal, which enhances their efficiency and facilitates determination of the current availability of micronutrients bound mainly to the exchangeable and carbonate fractions of the tested matrix.

The risk assessment code (RAC) calculated for Ni was as follows: $6.3 \%, 8.1 \%$ and $9.2 \%$ for TII, TI, and T0, respectively, and indicates a low environmental risk. Considering the above information, as well as the fact of the determined small amounts of Ni obtained by DTPA, it may confirm the environmental safety of the compost and fly ash, which directly limit the mobility, and thus reduces metal uptake by plants. In the case of soils contaminated with nickel it should be considered as a beneficial phenomenon; however, in unpolluted, intensively cultivated soil, such a phenomenon can become problematic, because of the above-mentioned reduction in nickel availability for plants.

The second applied extractant in the single extraction method- $\mathrm{HCl}$ extracted $29 \%, 30.4 \%$ and $37 \%$ of the total amount of nickel for soil fertilised with compost, fly ash and without fertilisation, respectively. Compared with the results of Korzeniowska and Stanisławska-Glubiak [7], the percentage shares of available nickel in this study were small, because the cited authors showed a much larger amount of extracted metal, representing $82-92 \%$ of the total amount of Ni. These differences between DTPA and $\mathrm{HCl}$ revealed in the present study are concurrent with outcomes obtained by Moreira et al. [27] or 
Jakubus and Bakinowska [28]. The higher amounts of metals extracted by the acid solution of $\mathrm{HCl}$ than the alkali solution of DTPA result from their different ionic strengths, and thus different properties and extractabilities. The significant extractive strength of $\mathrm{HCl}$ is indicated by the data in Figure 3 . The results obtained for $\mathrm{HCl}$ are comparable with those determined in fraction III (combinations of nickel with organic matter) (in the case of TI and TII) and with nickel in the residual fraction (in the case of control soil-T0).

The mean amounts of $\mathrm{Ni}$ determined in sequentially separated fractions increased in the following manner: Fr. I $<$ Fr. II $<$ Fr. III $<$ Fr. IV. This was independent of the additions used. The demonstrated quantitative distribution of nickel in the soil fractions is comparable to that presented in the literature [29-31], although the cited authors showed that the addition of organic matter or lime influenced the $\mathrm{Ni}$ amount in individual fractions. Malinowska [30] observed that application of sewage sludge caused a considerable increment of $\mathrm{Ni}$ in the organic fraction, while addition of lime decreased the amount of $\mathrm{Ni}$ in the mobile fraction. Nevertheless, the cited author in general stated that throughout the experiment there were no major changes in the forms of nickel. Liu et al. [31] using the BCR method of $\mathrm{Ni}$ speciation found the amount of $\mathrm{Ni}$ in the acetic acid-soluble fraction to decrease as the cow dung concentration increased and additionally $\mathrm{Ni}$ in the acetic acid-soluble and residual fractions transformed to the oxidisable fraction, leading to a lower environmental risk. On the other hand, Saffari et al. [29] proved that an addition of various amendments (coal fly ash, rice husk biochars, municipal solid waste compost, zero valent iron, zero valent manganese) reduced exchangeable and carbonate forms of $\mathrm{Ni}$ with respect to the control treatment. However, according to the cited authors, application of municipal solid waste compost on Ni stabilisation did not allow to formulate any conclusion about the positive effect of this amendment. Presented research also confirmed such a statement, because neither compost nor fly ash showed a distinct influence on $\mathrm{Ni}$ availability. As shown by data in Figures 1 and 2, in the separated fractions the amount of nickel always increased under the influence of the applied amendments. In comparison with the amount of $\mathrm{Ni}$ in the control soil, the amount of $\mathrm{Ni}$ in the soil of the TI and TII combination was significantly higher, although only at $12-20 \%$ in the case of Fr. I-III. In relation to the Ni level in the control soil a considerable 2.0- and 1.5-fold difference can be noticed in the case of nickel in the residual fraction in the soil fertilised with fly ash and compost, respectively. Such an increment of Ni introduced into the soil together with compost and fly ash should be interpreted as a unfavourable situation, but simultaneously it needs to be underlined that these amounts are safe for the environment, because they are found in the stable bonds of the organic matter (compost) and minerals (fly ash) without being mobile, hence, they are hardly accessible to plants. Nevertheless, it should be remembered that such a state is easy to destroy by changing environmental conditions, caused by the $\mathrm{pH}$ changes or by the mineralisation processes of organic matter.

\subsection{Nickel in Plants}

Referring to the stabilising/immobilising role of the applied amendments, they should be assessed first of all through the nickel accumulation in plant tissues. The data presented in relation to nickel in soil did not confirm the clear effect of either compost or fly ash on a possible smaller amount of Ni easily available for plants. However, analysis of plants grown in crop rotation may indicate such a possibility. Especially with regard to camelina and oat, such an assumption may be presented. Both plants grown under the control conditions had the largest amount of nickel, while in the case of soil fertilisation with compost (TI) or fly ash (TII) the amount of the metal in plants was significantly lower. A reverse trend was demonstrated for lupine cultivated in the first year of the study. Plants cultivated in the soil fertilised with fly ash had the highest amounts of this metal. According to Gupta et al. [14], among many plants those belonging to Leguminous (Fabaceae Lindl.) are especially predisposed for growing in soils enriched with fly ash. Additionally, members of this family usually accumulate more $\mathrm{Ni}$ than other plant species $[5,26]$. Among the plants cultivated in the experiment the smallest amounts of $\mathrm{Ni}$ were determined for oat, which is also confirmed by the literature [3,5]. It could be caused by 
the fact that roots of monocots generally have a lower CEC than roots of dicots and thus they would have a smaller pool of $\mathrm{Ni}$ in the roots for translocation to the shoots. Additionally, most frequently monocotyledonous plants assimilate lesser amounts of micronutrients, including $\mathrm{Ni}$, in comparison to dicotyledonous plants.

Regardless of physiological differences between plants, the contents of $\mathrm{Ni}$ in lupine and oat first of all were determined by the amount of nickel in fraction I (Table 3). These relationships were the strongest under the control soil conditions, and distinctly smaller when the soil was enriched with fly ash or compost. In the case of camelina, the Ni content in its tissues was primarily determined by the bioavailable amounts of $\mathrm{Ni}$ and also it was most strongly stressed in the control soil and less in the case of amendments introduced into the soil.

In addition to the above-mentioned regression equations, also the values of bioconcentration factors show the significance of Ni extracted either with DTPA or acetic acid (Fr. I in BCR method) (Figure 6). Independently of the cultivated plant, the calculated BCF values were comparable, which may suggest an important diagnostic role of this indicator. Thus the discussed issue of nickel accumulation in plants in relation to its bioavailability in soil should also be interpreted using the bioconcentration factor. The bioconcentration factor (BCF) is a popular indicator used to evaluate heavy metal toxicity as well as their translocations from soil to plants [1,8,32]. Additionally, Hu et al. [33] stated that the bioconcentration values rather than the total contents of heavy metals should be taken into consideration. In this study, apart from the common $\mathrm{BCF}_{\mathrm{T}}$, additionally the bioconcentration factors based on nickel contents in the separated fractions $\left(\mathrm{BCF}_{\mathrm{I}}, \mathrm{BCF}_{\mathrm{II}}, \mathrm{BCF}_{\mathrm{III}}, \mathrm{BCF}_{\mathrm{IV}}\right)$, as well as available $\left(\mathrm{BCF}_{\mathrm{A}}\right)$ and bioavailable amounts $\left(\mathrm{BCF}_{\mathrm{B}}\right)$ were calculated. The influence of the compost or fly ash was stressed at lower values of all bioconcentration factors calculated for camelina and oat. On the other hand, for lupine, the lower values of all discussed coefficients were determined for the control soil and the soil enriched with compost. The significant influence of compost amendment on $\mathrm{BCF}_{\mathrm{T}}$ and $\mathrm{BCF}_{\mathrm{B}}$ values of $\mathrm{Cu}$ and $\mathrm{Zn}$ calculated for winter barley and white mustard was proved by [24]. Moreover, a positive effect of biochar, gravel sewage, and zeolite expressed by the reduction of values $\mathrm{BCF}$ of $\mathrm{Ni}$ for red clover was found in [8].

\section{Conclusions}

Statistical analysis confirmed both the functions of compost and fly ash both fertilising (increase of the nickel compared to the control soil) and immobilisation (reduction of the amount of nickel readily available for plants). Although the amounts of Ni extracted by DTPA did not undergo significant changes under the influence of the used amendments, similarly to the amounts of exchangeable Ni (Fr. I), they determined the metal content in cultivated plants. Obtained results indicate a possibility of nickel accumulation in plants interpreted in relation to its bioavailability in soil using the bioconcentration factor. Based on the bioconcentration factor, the addition of compost or fly ash in a similar way influenced Ni contents in camelina and oat. The use of selected statistical methods made it possible to present a significant variation of nickel contents among sequentially separated fractions (I-IV) as well as the available, bioavailable, and total amounts of the metal in soil. In particular, the presented hierarchical methods gave the opportunity to indicate the most important $\mathrm{Ni}$ bonds determining its content in the plants depending on the applied fertilisation. It should be noted that the results regarded to the use of multiple regression to determine the linear relationship between $\mathrm{Ni}$ content in soil and its amount in plants needs more research and must be checked by repetition in a more complex design.

Author Contributions: Conceptualization and investigation, M.J.; methodology, M.J., M.G.; project administration, M.J.; data curation, M.J., M.G.; writing—original draft, M.J., M.G.; writing—review and editing, M.J., M.G.; funding acquisition, M.G. All authors have read and agreed to the published version of the manuscript.

Funding: This research received no external funding.

Conflicts of Interest: No potential conflict of interest was reported by the authors. 


\section{References}

1. Correia, L.; Marrocos, P.; Olivares, D.M.M.; Garcia, F.C.; Luzardo, F.H.M.; De Jesus, R.M. Bioaccumulation of nickel in tomato plants: Risks to human health and agro-environmental impacts. Environ. Monit. Assess. 2018, 190, 317. [CrossRef]

2. Ameen, N.; Amjad, M.; Murtaza, B.; Abbas, G.; Shahid, M.; Imran, M.; Naeem, M.A.; Niazi, N.K. Biogeochemical behavior of nickel under different abiotic stresses: Toxicity and detoxification mechanisms in plants. Environ. Sci. Pollut. Res. 2019, 26, 10496-10514. [CrossRef]

3. Gupta, V.; Jatav, P.K.; Verma, R.; Kothari, S.L.; Kachhwaha, S. Nickel accumulation and its effect on growth, physiological and biochemical parameters in millets and oats. Environ. Sci. Pollut. Res. 2017, 24, 23915-23925. [CrossRef]

4. Kabata-Pendias, A.; Pendias, H. Biogeochemistry of Trace Elements; PWN: Warszawa, Poland, 1999; pp. $306-315$. (In Polish)

5. Cioccio, S.; Gopalapillai, Y.; Dan, T.; Hale, B. Effect of liming on nickel bioavailability and toxicity to oat and soybean grown in field soils containing aged emissions from a nickel refinery. Environ. Toxicol. Chem. 2016, 36, 1110-1119. [CrossRef]

6. Jakubus, M.; Graczyk, M. Evaluation of the usability of single extractors in chemical analysis of composts using principal component analysis. Biom. Lett. 2015, 52, 115-130. [CrossRef]

7. Korzeniowska, J.; Stanisławska-Glubiak, E. Proposal of new convenient extractant for assessing phytoavaialbility of heavy metals in contaminated sandy soil. Environ. Sci. Pollut. Res. 2017, 24, 14857-14866. [CrossRef]

8. Shahbaz, A.K.; Iqbal, M.; Jabbar, A.; Hussain, S.; Ibrahim, M. Assessment of nickel bioavailability through chemical extractants and red clover (Trifolium pretense L.) in an amended soil: Related changes in various parameters of red clover. Ecotoxicol. Environ. Saf. 2018, 149, 116-127. [CrossRef] [PubMed]

9. Rao, C.R.M.; Sahuquillo, A.; López-Sánchez, J.F. A Review of the Different Methods Applied in Environmental Geochemistry for Single and Sequential Extraction of Trace Elements in Soils and Related Materials. Water Air Soil Pollut. 2008, 189, 291-333. [CrossRef]

10. European Commission. Communication from the Commission to the European Parliament, the Council, the European Economic and Social Committee and the Committee of the Region-Toward a Circular Economy: Zero Waste Programme For Europe; European Commission: Brussels, Belgium, 2014. Available online: https://eur-lex.europa.eu/ resource.html?uri=cellar:aa88c66d-4553-11e4-a0cb-01aa75ed71a1.0022.03/DOC_1\&format=PDF (accessed on 2 July 2020).

11. Deepesh, V.; Verma, V.K.; Suma, K.; Ajay, S.; Gnanavelu, A.; Madhusudanan, M. Evaluation of an organic soil amendment generated from municipal solid waste seeded with activated sewage sludge. J. Mater. Cycles Waste Manag. 2014, 18, 273-286. [CrossRef]

12. Sharma, B.; Sarkar, A.; Singh, P.; Singh, R.P. Agricultural utilisation of biosolids: A review on potential effects on soil and plant grown. Waste Manag. 2017, 64, 117-132. [CrossRef] [PubMed]

13. Jakubus, M.; Bakinowska, E.; Gałka, B. The quantitative changes of nutrients in two contrasting soils amended with sewage sludge compost evaluated by various statistical tools. Acta Agric. Scand. Sect. B Plant Soil Sci. 2017, 68, 39-49. [CrossRef]

14. Gupta, D.K.; Rai, U.N.; Tripathi, R.D.; Inoute, M. Impacts of fly-ash on soil and plant responses. J. Plant Res. 2002, 115, 401-409. [CrossRef] [PubMed]

15. FAO. WRB (World Reference Base for Soil Resources) 2014; Update, World Soil Resources Reports, 106; FAO: Rome, Italy, 2015.

16. Ministry of Agriculture and Rural Development. Regulation of the Minister for Agriculture and Rural Development of 18 June 2008 on the Implementation of Certain Provisions of the Act on Fertilisers and Fertilisation; Journal of Laws 2008, 119, Item 765; Ministry of Agriculture and Rural Development: Warsaw, Poland, 2008.

17. International Organization of Standardization. Soil Quality-Extraction of Trace Elements Soluble in Aqua Regia; ISO 11466; International Organization of Standardization: Geneva, Switzerland, 1995.

18. Ostrowska, A.; Gawliński, S.; Szczubialka, Z. Methods for Analysis and Evaluation of Soil and Plant Properties, 1st ed.; IOŚ Warszawa: Warsaw, Poland, 1991; pp. 158-167.

19. Gembarzewski, H.; Korzeniowska, J. Simultaneous extraction of B, Cu, Fe, Mn, Mo and Zn from mineral soils and an estimation of the results. Agribiol. Res. Z. Agrarbiol. Agrik. Okol. 1990, 43, 115-127. 
20. Quevauviller, P.; Lachica, M.; Barahona, E.; Gomez, A.; Rauret, G.; Ure, A.; Muntau, H. Certified reference material for the quality control of EDTA- and DTPA- extractable trace metals contents in calcareous soil (CMR 600). Fresenius J. Anal. Chem. 1998, 360, 505-511. [CrossRef]

21. Mossop, K.F.; Davidson, C.M. Comparison of original and modified BCR sequential extraction procedures for the fractionation of copper, iron, lead, manganese and zinc in soils and sediments. Anal. Chim. Acta 2003, 478, 111-118. [CrossRef]

22. Yang, T.; Huang, H.-J.; Lai, F.-Y. Pollution hazards of heavy metals in sewage sludge from four wastewater treatment plants in Nanchang, China. Trans. Nonferrous Met. Soc. China 2017, 27, 2249-2259. [CrossRef]

23. Park, J.H.; Lamb, D.; Paneerselvam, P.; Choppala, G.; Bolan, N.; Chung, J.W. Role of organic amendments on enhanced bioremediation of heavy metal(loi) contaminated soils. J. Hazard. Mater. 2011, 185, 549-574. [CrossRef]

24. Jakubus, M.; Bakinowska, E.; Tatuśko, N. Compost utilisation in a heavy metal immobilisation process evaluated by bioconcentration factors. J. Elementol. 2019, 24, 1291-1307. [CrossRef]

25. Raja, R.; Pal, S. Remediation of heavy metal contaminated soils by solidification/stabilization with fly ash, quicklime and blast furnance slag. J. Indian Chem. Soc. 2019, 96, 481-486.

26. Luo, D.; Zheng, H.; Chen, Y.; Deleporte, P.; Xie, T.; Staunton, S.; Wang, G. Influence of soil properties on Ni accumulation in food crops and corresponding dietary health risk with a typical Chinese diet. Soil Use Manag. 2017, 33, 653-662. [CrossRef]

27. Moreira, S.G.; Prochnow, L.I.; Kiehl, J.D.C.; Pauletti, V.; Martin-Neto, L. Chemical forms in soil and availability of manganese and zinc to soybean in soil under different tillage systems. Soil Tillage Res. 2016, 163, 41-53. [CrossRef]

28. Jakubus, M.; Bakinowska, E. Visualization of long-time quantitative changes of microelements in soils amended with sewage sludge compost evaluated with two extraction solutions. Commun. Soil Sci. Plant Anal. 2018, 49, 11, 1355-1369. [CrossRef]

29. Saffari, M.; Karimian, N.; Ronaghi, A.; Yasrebi, J.; Ghasemi, R. Stabilization of nickel in a contaminated calcareous soil amended with low-cost amendments. J. Soil Sci. Plant Nutr. 2015, 15, 896-913. [CrossRef]

30. Malinowska, E. The Effect of Liming and Sewage Sludge Application on Heavy Metal Speciation in Soil. Bull. Environ. Contam. Toxicol. 2017, 98, 105-112. [CrossRef]

31. Liu, B.; Huang, Q.; Su, Y.; Wang, M.; Yu, H.; Sun, L. Speciation of nickel and enzyme activities in fluvo-aquic soil under organic amendments treatment. Soil Res. 2018, 56, 456. [CrossRef]

32. Boim, A.G.F.; Melo, L.C.A.; Moreno, F.N.; Alleoni, L.R.F. Bioconcentration factors and the risk concentrations of potentially toxic elements in garden soils. J. Environ. Manag. 2016, 170, 21-27. [CrossRef]

33. Hu, B.; Ja, X.; Hu, J.; Xu, D.; Xia, F.; Li, Y. Assessment of heavy metal pollution and health risks in the soil-plant-human system in the Yangtze River Delta, China. Int. J. Environ. Res. Public Health 2017, 14, 1042. [CrossRef]

Publisher's Note: MDPI stays neutral with regard to jurisdictional claims in published maps and institutional affiliations.

(C) 2020 by the authors. Licensee MDPI, Basel, Switzerland. This article is an open access article distributed under the terms and conditions of the Creative Commons Attribution (CC BY) license (http://creativecommons.org/licenses/by/4.0/). 